\title{
Primary Structure and Physical Properties of New Superalloys Co-20Ni-10Al-5Mo-2Nb on Cobalt Matrix
}

\author{
A. Tomaszewska ${ }^{a}$, M. Kierat $^{a}$, G. Moskal $^{a, *}$ And A. Zieliński ${ }^{b}$ \\ ${ }^{a}$ Silesian University of Technology, Department of Advanced Materials and Technologies, \\ Z. Krasińskiego 8, 40-019 Katowice, Poland \\ ${ }^{b}$ Eukasiewicz Research Network of Institute for Ferrous Metallurgy, \\ K. Miarki 12-14, 44-100 Gliwice, Poland
}

Doi: 10.12693/APhysPolA.138.129

*e-mail: grzegorz.moskal@polsl.pl

\begin{abstract}
In the study we investigated the primary structure and physical properties of the new generation of superalloys based on $\mathrm{Co}_{10} \mathrm{Al}_{5} \mathrm{Mo}_{2} \mathrm{Nb}$ type cobalt. The microstructural investigations were carried out with a scanning electron microscope on conventionally prepared electrolytically etched metallographic microsections. The studies of microstructure using a transmission electron microscope were performed using thin films. The testing of mechanical properties in the as-received condition included the performance of static tensile test at room temperature using a testing machine with a maximum load of $200 \mathrm{kN}$. These materials may replace nickel-based superalloys in the future due to their excellent properties at elevated temperatures relative to nickel-based superalloys. Currently, nickel-strengthened $\gamma^{\prime}$ phase steels are still unrivalled in aerospace applications. However, cobalt-based superalloys are a response to their existing limitations, which do not allow maintaining the current rate of development of aircraft engines.
\end{abstract}

topics: $\mathrm{Co}-\mathrm{Ni}-\mathrm{Al}-\mathrm{Mo}-\mathrm{Nb}$, casting, primary microstructure, segregation, dendrites

\section{Introduction}

The mechanical and magnetic properties of Co-based alloys often depend on the production method [1-3]. In the case of products for the aviation industry, materials working at high temperatures (superalloys) are sought. Superalloys based on $\mathrm{Ni}$ or $\mathrm{Co}$ are high-performance materials used usually in high-temperature elements of land-based and aircraft turbines such as discs, blades, rotating shafts, nozzle guide vanes, and combustor liners [4-9]. Between them, the Co-based superalloys have applications as critical turbine engine parts, where hot corrosion, wear, and oxidation resistance are required [10, 11]. Theirs lower strength values (due to limits in strengthening with solid solution/carbide precipitation) make them unusable for blade and disk applications and they are mainly used in static parts such as vanes [10]. The most popular and widely used alloys from this group are for example Hayens 188, Mar-M and stellite. Those alloys are strengthened by solid solution $\mathrm{Co}_{s s}$ and carbides of refractory elements, but its high temperature properties such as creep resistance is lower than Ni-based superalloys due to lack of $\gamma / \gamma^{\prime}$ structure [12-14]. Recent investigations showed that there is possibility of $\gamma / \gamma^{\prime}$ structure creation in Cobased superalloys of $\mathrm{Co}-\mathrm{Al}-\mathrm{X}$ type where $\mathrm{X}=\mathrm{W}$, $\mathrm{Mo}, \mathrm{Nb}$, Ta, and the main strengthened mechanism is related with presences of $\mathrm{Co}_{3}(\mathrm{Al}, \mathrm{X})$ with $\mathrm{L}_{2}$ type of lattice [15-19]. Addition of $\mathrm{W}$ and $\mathrm{Al}$ with proper proportion in Co stabilizes the $\gamma^{\prime}$ structure with the stoichiometry $\mathrm{Co}_{3}(\mathrm{Al}, \mathrm{W})$ that are stable up to $900^{\circ}[12,20]$. The addition of Mo as an alloying element should get similar structural effects with additional decrease of alloys density. The extent of replacement in these cases is only up to 3 at. $\%$, beyond which equilibrium phase $\mathrm{Co}_{3} \mathrm{Mo}$ with D0 19 ordered structure appears [18]. In comparison to $\mathrm{Co}_{3}(\mathrm{Al}, \mathrm{W})$ there is no data confirmed existence of $\mathrm{Co}_{3}(\mathrm{Al}, \mathrm{Mo})$ phase with $L 1_{2}$ type of structure. $L 1_{2}$ ordering does not take place on ageing between $600^{\circ}$ and $800^{\circ}[16]$. It was revealed that small addition of $\mathrm{Nb}$ or Ta plays a critical role in stabilizing of $\gamma-\gamma^{\prime}$ microstructure [17-19]. The development of $\mathrm{Co}-\mathrm{Al}-\mathrm{Mo}-\mathrm{Nb}$ alloys started in 2015 when the first information was presented by Makineni et al. [18, 19]. The microstructure of this alloy is analogous to $\mathrm{Co}-\mathrm{Al}-\mathrm{W}$ alloys with cuboidal $\gamma^{\prime}-\mathrm{Co}_{3}(\mathrm{Al}, \mathrm{Mo}, \mathrm{Nb})$ precipitates coherently distributed in a $\gamma$-fcc Co-based matrix. The density of the W-free alloys is decreased to $8.4 \mathrm{~g} / \mathrm{cm}^{3}$ when compared to $9.2 \mathrm{~g} / \mathrm{cm}^{3}$ for $\mathrm{Co}-7 \mathrm{Al}-7 \mathrm{~W}$ [19].

The basic goals of presented investigations are characterization of primary microstructure of $\mathrm{Co}-20 \mathrm{Ni}-10 \mathrm{Al}-5 \mathrm{Mo}-2 \mathrm{Nb}$ alloy and, identification of segregation effect of chemical constituent, with special emphasis to detection in Mo and $\mathrm{Nb}$ concentration in dendritic and interdendritic areas. Another important element is analysis 
TABLE I

Nominal chemical composition of analyzed $\mathrm{Co}-20 \mathrm{Ni}-$ $10 \mathrm{Al}-5 \mathrm{Mo}-2 \mathrm{Nb}$ alloy.

\begin{tabular}{c|c|c|c|c|c}
\hline \hline & $\mathrm{Ni}$ & $\mathrm{Al}$ & $\mathrm{Mo}$ & $\mathrm{Nb}$ & $\mathrm{Co}$ \\
\hline at.\% & 20.0 & 10.0 & 5.0 & 2.0 & bal. \\
wt\% & 18.3 & 4.7 & 8.4 & 2.1 & bal.
\end{tabular}

of $\mathrm{Ni}$ addition influence on primary microstructure, as well as the precipitation volume, chemical composition and its morphology for modified Co-10Al-5Mo-2Nb alloy [21].

\section{Experiment and materials}

The nominal composition of used in investigations cobalt based superalloy of $\mathrm{Co}-\mathrm{Ni}-\mathrm{Al}-\mathrm{Mo}-\mathrm{Nb}$ type is present in Table I. The alloy was melted using induction vacuum furnace VSG 02 Balzers, in $\mathrm{Al}_{2} \mathrm{O}_{3}$ crucibles, set in a coil using manually compacted molding sand Konmix MAPI. The melting process was realized under argon Alphagaztm $1 \mathrm{Ar}$ (99.999\% Ar). Before melting, a chamber of furnace was three times washed by argon blowing, then the pressure inside was reduced to value of $10^{-3} \mathrm{Tr}$ $(\approx 0.13 \mathrm{~Pa})$ and subsequently, the chamber was gas filled to operating pressure $600 \operatorname{Tr}(\approx 800 \mathrm{hPa})$. As input materials, the high purity metals were utilized, wherein the main components of alloys were: electrolytic cobalt (minimum 99.98\% Co), aluminum $3 \mathrm{~N} 8(99.98 \% \mathrm{Al})$, and technical quality molybdenum and niobium. Cobalt and aluminum were directly placed into crucible before melting, whereas the rest of alloying elements was being added to liquid solution after its homogenization (dosing during melting process). The base alloy was melted in the temperature range $1650-1750^{\circ} \mathrm{C}$. The time of melting was approximately $10 \mathrm{~min}$. Co-based alloys were casted under argon atmosphere into cold graphite molds.

Scanning electron microscopy (SEM) imaging of microstructure and chemical state of surfaces were carried out on a INSPECT F scanning microscope, equipped with an energy dispersive X-ray spectroscopy (EDS).

\section{Results and discussion}

First, as-cut sample was used for preparation of transverse cross-section ( $\mathrm{T}$ ) and, second, for longitudinal (L) one. The stereoscopic view of etched samples of both type was shown in Fig. 1. The electrolytic etching in solution containing $25 \mathrm{ml} \mathrm{H}_{2} \mathrm{O}$, $50 \mathrm{ml} \mathrm{HCl}, 15 \mathrm{~g} \mathrm{FeCl}_{3}, 3 \mathrm{~g} \mathrm{CuCl}_{2} \cdot \mathrm{NH}_{4} \mathrm{Cl} \cdot 2 \mathrm{H}_{2} \mathrm{O}$ was used.

Light microscopy illustrated morphology of columnar and equiaxed grains present in both dominates crystal zones is shown in Fig. 2. It can be seen that the columnar zone has a shape of highly elongated dendritic cells with visible dendrites of first and second level.

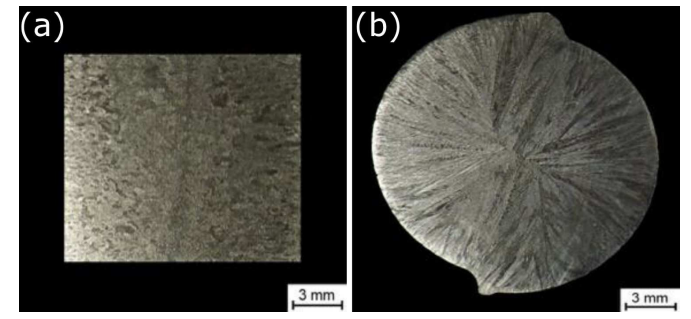

Fig. 1. General view of primary microstructure of Co-20Ni-10Al-5Mo-2Nb alloy in as-cast condition: transverse (a) and longitudinal (b) section.
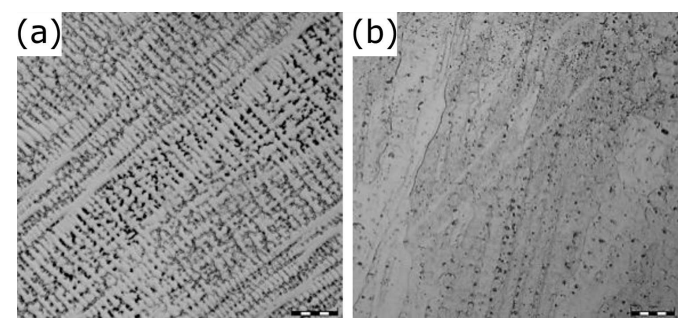

Fig. 2. Light microscopy illustrated primary microstructure of $\mathrm{Co}-20 \mathrm{Ni}-10 \mathrm{Al}-5 \mathrm{Mo}-2 \mathrm{Nb}$ alloy in as-cast condition: transverse (a) and longitudinal (b) section.
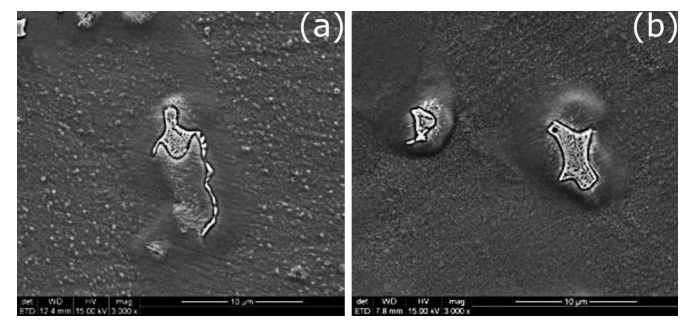

Fig. 3. SEM microstructure of (a) $\mathrm{Co}-20 \mathrm{Ni}-10 \mathrm{Al}-$ $5 \mathrm{Mo}-2 \mathrm{Nb}$ alloy in as cast condition - longitudinal view, (b) transverse view.

Locally the ovules of third level dendrites are visible as well. In the second case of grains with the equiaxed morphology, they have a form of fine crystals of poorly expanded dendrites oriented randomly to other. Visible contrast between dendrite cores areas and interdendritic areas is a consequence of substantial dendritic alloying elements microsegregation in alloys after casting.

Detailed analysis of chemical composition of basic alloy are related to analysis of microstructure. Those data are shown in Figs. 3 and 4, where microstructure on longitudinal and transverse section of rods is presented. In both cases the four basic zones can be identified. Three in the areas of interdendritic zone, and one which corresponds to cores of dendrites. Comparison of alloy's microstructure for both cross-sections showed that in the case of longitudinal cross-section the location of precipitation in interdendritic zone is much more random than for the transverse cross-section, where the more linear distribution of this zones can be observed. 


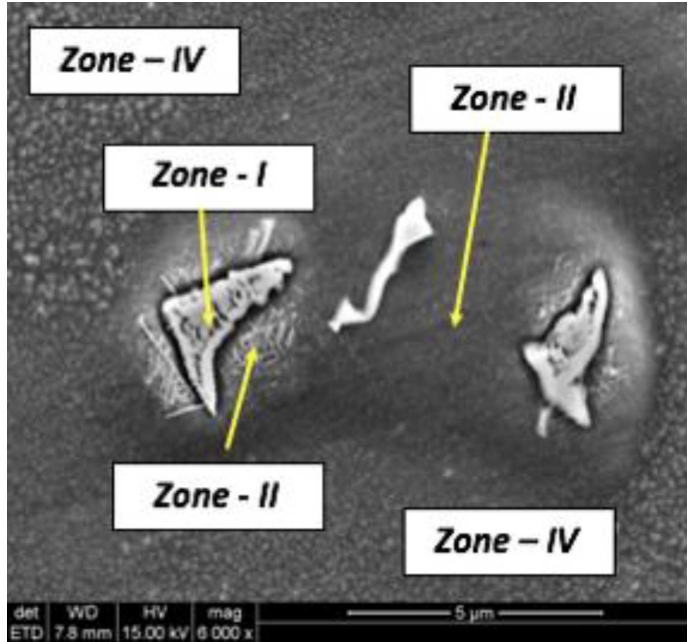

Fig. 4. Detailed localization of structural zone from I to IV in $\mathrm{Co}-20 \mathrm{Ni}-10 \mathrm{Al}-5 \mathrm{Mo}-2 \mathrm{Nb}$ alloy in as-cast condition (SEM).

Detailed analysis of interdendritic zone revealed presence of three subzones mentioned earlier. First of them consists of precipitation in the morphology typical for eutectics (Fig. 3a, 3b). In direct surroundings of this structural element, there can be defined another one element with other chemical composition and needle-like morphology. This zone is probably related with "cutting" of precipitation during cross-sections of samples. The morphology of observed elements suggests the presence of eutectic of $\mathrm{Co} / \mathrm{Co}_{3}(\mathrm{Al}, \mathrm{Mo}, \mathrm{Nb}$ ) (first zone) type with nodular precipitation of $\mathrm{Co}_{3} \mathrm{Mo}$ and $/$ or $\mathrm{Co}_{3} \mathrm{Nb}$ phase with $\mathrm{D}_{19}$ type of lattice (second zone).

The third visible structurally other areas is sheath of this two subzones without presences of eutectic form but with very ultrafine-grained precipitations of probably primary $\mathrm{L}_{2}$ phase with formula $\mathrm{Co}_{3}(\mathrm{Al}, \mathrm{Mo}, \mathrm{Nb})$. The last identified morphological form is Co based solid solution as a matrix with fine-grained precipitation of probably primary $\mathrm{L}_{2}$ phase with formula $\mathrm{Co}_{3}(\mathrm{Al}, \mathrm{Mo}, \mathrm{Nb})$. In comparison to earlier mentioned ultrafine-grained precipitations, in this zone this structural element is much higher in size, and shape similar to spheroidal or cuboidal.

Analysis of chemical composition in these areas revealed that alloying element Mo is relatively uniformly distributed in all microstructures of analyzed alloy, contrary to $\mathrm{Nb}$. $\mathrm{Nb}$ was identified mainly in precipitations in interdendritic zones and its direct neighborhood. It suggests the presence of $\mathrm{Co}_{3}(\mathrm{Al}$, $\mathrm{Mo}, \mathrm{Nb})$ phase, as well as $\mathrm{Co}_{3}(\mathrm{Nb}, \mathrm{Mo})$ in the form of eutectic system with Co-based solid solution.

As mentioned earlier the morphology of this precipitation conforms these suggestions. Interesting observations were made in zone III, where practically pure Co-based solid solution was identified with small addition of ultrafine precipitations (suggestion of ultrafine grained $\mathrm{Co}_{3}(\mathrm{Al}, \mathrm{Mo}, \mathrm{Nb})$ phase
TABLE II

Measured chemical composition of analyzed $\mathrm{Co}-$ $20 \mathrm{Ni}-10 \mathrm{Al}-5 \mathrm{Mo}-2 \mathrm{Nb}$ alloy.

\begin{tabular}{c|c|c|c|c|c}
\hline \hline Zone & Co & $\mathrm{Ni}$ & $\mathrm{Al}$ & $\mathrm{Mo}$ & $\mathrm{Nb}$ \\
\hline \multicolumn{6}{c}{ at. \% } \\
\hline I & 57.89 & 13.87 & 4.95 & 6.82 & 16.58 \\
II & $59.20 \uparrow$ & $19.27 \uparrow$ & $8.67 \uparrow$ & $5.65 \downarrow$ & $7.22 \downarrow$ \\
III & $59.23 \uparrow$ & $20.20 \uparrow$ & $9.02 \uparrow$ & $5.97 \downarrow$ & $5.58 \downarrow$ \\
IV & $62.72 \uparrow$ & $21.31 \uparrow$ & $9.52 \uparrow$ & $4.88 \downarrow$ & $1.58 \downarrow$ \\
\hline \multicolumn{6}{c}{$\mathrm{wt} \%$} \\
\hline I & 52.01 & 12.43 & 2.04 & 9.99 & 23.53 \\
II & $57.51 \uparrow$ & $18.65 \uparrow$ & $3.86 \uparrow$ & $8.94 \downarrow$ & $11.05 \downarrow$ \\
III & $58.07 \uparrow$ & $19.73 \uparrow$ & $4.05 \uparrow$ & $9.53 \downarrow$ & $8.62 \downarrow$ \\
IV & $63.53 \uparrow$ & $21.50 \uparrow$ & $4.42 \uparrow$ & $8.04 \downarrow$ & $2.52 \downarrow$
\end{tabular}

presences). This microstructural effect suggests also the impoverishment to alloying elements such as $\mathrm{Mo}$ and $\mathrm{Nb}$ (in contrary to chemical composition analysis in this zone presented in Table II), but the relatively high concentration of those elements can be related to subsurface detection of Mo and $\mathrm{Nb}$ from strongly internal developed precipitation form zone I. The small volume and size of primary $\mathrm{Co}_{3}(\mathrm{Al}, \mathrm{Mo}, \mathrm{Nb})$ phase in this zone can be explained by consumption of $\mathrm{Mo}$ and $\mathrm{Nb}$ by bigger precipitation and lack of enough concentration of them to formation of $\mathrm{Co}_{3}(\mathrm{Al}, \mathrm{Mo}, \mathrm{Nb})$ phase during solidification.

\section{Conclusions}

The primary microstructure of $\mathrm{Co}-20 \mathrm{Ni}-10 \mathrm{Al}-$ $5 \mathrm{Mo}-2 \mathrm{Nb}$ analysis revealed the strong effect on alloying elements segregations during solidification process in graphite molds. The strongest tendency to interdendritic segregation was identified in the case of $\mathrm{Nb}$ addition. Much lower tendency to segregation was observed in the case of Mo alloying element.

The formation of probably $\mathrm{Co}_{3} \mathrm{Nb}$ and $\mathrm{Co}_{3} \mathrm{Mo}$ phase was observed in interdendritic zone, as well as the eutectic structure of $\mathrm{Co}_{s s} / \mathrm{Co}_{3}(\mathrm{Al}, \mathrm{Mo}, \mathrm{Nb})$ type. Both structural elements showed different morphological form. Formation of those structural elements causes a depletion of the solution in niobium and molybdenum (in lower scale) in direct neighborhood and decreasing tendency to formation of primary $\mathrm{Co}_{3}(\mathrm{Al}, \mathrm{Mo}, \mathrm{Nb})$ phase.

Areas of the dendrite core which are rich in Mo and $\mathrm{Nb}$ (in solid solution) revealed much stronger tendency to formation of primary $\mathrm{Co}_{3}(\mathrm{Al}, \mathrm{Mo}, \mathrm{Nb})$ phase in the form of spherical/cuboidal form.

\section{Acknowledgments}

This work was supported by National Science Centre (Project 2018/29/N/ST8/02062). 


\section{References}

[1] S. Lesz, P. Kwapuliński, M. Nabiałek, P. Zackiewicz, L. Hawelek, J. Thermal Anal. Calorim. 125, 1143 (2016).

[2] M. Nabialek, B. Jez, K. Jez, P. Pietrusiewicz, K. Bloch, J. Gondro, M.M.A.B. Abdullah, A.V. Sandu, IOP Conf. Series Mater. Sci. Eng. 572, 012018 (2019).

[3] R.S. Sunmonu, J.O. Akinlami, E.O. Dare, G.A. Adebayo, Computat. Condens. Matter 21, e00412 (2019).

[4] R.C. Reed, The Superalloys Fundamentals and Applications, Cambridge University Press, 2006.

[5] T. Dudziak, V. Deodeshmukh, L. Backert, et al., Oxid. Met. 87, 139 (2017).

[6] A. Zieliński, J. Dobrzański, H. Purzyńska, R. Sikora, M. Dziuba-Kałuża, Z. Kania, Arch. Metall. Mater. 62, 2057 (2017).

[7] M. Sroka, A. Zieliński, A. Hernas, Z. Kania, R. Rozmus, T. Tański, A. Śliwa, Metalurgija 56, 333 (2017).

[8] M. Sroka, M. Nabiałek, M. Szota, A. Zieliński, Rev. Chim. Bucharest 684, 737 (2017).

[9] A. Śliwa, W. Kwaśny, M. Sroka, R. Dziwis, Metalurgija 56, 422 (2017).
[10] D. Coutsouradis, A. Davin, M. Lamberigts, Mater. Sci. Eng. A 88, 11 (1987).

[11] D.L. Douglass, V.S. Bhide, E. Vineberg, Oxid. Met. 16, 29 (1981).

[12] S.G. Kang, T. Kobayashi, Mater. Sci. Forum 449-452, 573 (2004).

[13] W.H. Jiang, X.D. Yao, H.R. Guan, Z.Q. Hu, J. Mater. Sci. Lett. 8, 303 (1999).

[14] W.H. Jiang, X.D. Yao, H.R. Guan, Z.Q. Hu, J. Mater. Sci. 4, 2859 (1999).

[15] J. Sato, T. Omori, K. Oikawa, I. Ohnuma, R. Kainuma, K. Ishida, Science 312, 90 (2006).

[16] C.S. Lee, Ph.D. Thesis, University of Arizona, 1971.

[17] S.K. Makineni, B. Nithin, K. Chattopadhyay, Scr. Mater. 98, 36 (2015).

[18] S.K. Makineni, A. Samanta, T. Rojhirunsakool, T. Alam, B. Nithin, A.K. Singh, R. Banerjee, Acta Mater. 97, 29 (2015).

[19] S.K. Makineni, B. Nithin, Acta Mater. 85, 85 (2015).

[20] N. Eliaz, G. Shemesh, R.M. Latanision, Eng. Fail. Anal. 9, 31 (2002).

[21] A. Tomaszewska, T. Mikuszewski, G. Moskal, J. Alloys Compd. 750, 741 (2018). 